\title{
Application of Peptides Containing the Cleavage Sequence of Pro-TNF $\alpha$ in Assessing TACE Activity of Whole Cells
}

\author{
Bernhard F. Becker ${ }^{1, *}$, Stefanie Gilles ${ }^{1}$, \\ Christian P. Sommerhoff ${ }^{2}$ and Stefan Zahler ${ }^{1}$ \\ ${ }^{1}$ Department of Physiology, \\ ${ }^{2}$ Department of Clinical Biochemistry, University of \\ Munich, D-80336 Munich, Germany \\ ${ }^{*}$ Corresponding author
}

Tumor necrosis factor- $\alpha$ (TNF $\alpha)$ is presumably shed from cell membranes by TNF $\alpha$-cleaving enzyme (TACE). The peptides SPLAQAVRSSSR and DabcylLAQAVRSSSR-Edans, each encompassing the cleavage sequence of pro-TNF $\alpha$ recognized by TACE, were applied to intact umbilical vein endothelium (HUVEC), peripheral blood leukocytes (PBL) and the mast cell line HMC-1, which express TACE, to homogenates of rat heart tissue and to membrane and cytoplasmic extracts of PBL. Formation of SPLAQA (specific cleavage) was determined by HPLC, while cleavage (specific plus non-specific) of Dabcyl-TNF $\alpha$-Edans was followed over time by measuring fluorescence. Participation of TACE was assessed from inhibition due to the drug TAPI-2. Incubation with recombinant human TACE gave specific cleavage, fully inhibitable by TAPI-2 $\left(\mathrm{IC}_{50}<0.1 \mu \mathrm{M}\right)$. HUVEC rapidly degraded TNF $\alpha$-peptide, but in a non-specific manner (no SPLAQA detectable) and $50 \mu \mathrm{M}$ TAPI-2 was without effect. Fluorescence was evoked when DabcylLAQAVRSSSR-Edans was incubated with HMC-1 or PBL and also with cytoplasmic and membrane fractions of lysed PBL, but in no case was there significant inhibition by TAPI-2. However, marginal (10\%) inhibition of fluorescence by $50 \mu \mathrm{M}$ TAPI-2 was observed with homogenized heart tissue. This contained TACE, about $75 \%$ of which was without the inhibitory cysteine switch (Western blot). In conclusion, simple peptide analogs of pro-TNF $\alpha$ cannot be employed as substrates for measuring membrane TACE activity, largely due to extensive non-specific proteolytic cleavage by whole cells and cell extracts.

Key words: Human umbilical vein endothelial cells / Mast cells/Metalloproteinase/Oxidative stress/ Peripheral blood leukocytes/TAPI.
The shedding and liberation of the $17 \mathrm{kDa}$ inflammatory cytokine TNF $\alpha$ requires for this cytokine to be first cleaved from its $24 \mathrm{kDa}$ pro-form expressed in cell membranes at the scissile Ala76-Val77 bond. This process is presumed to rely largely on the action of metalloproteinase sheddases, foremost the TNF $\alpha$-cleaving enzyme (TACE or ADAM17) (Black et al., 1997). However, native TACE contains an inhibitory cysteine switch, removal of which seems a prerequisite for enzyme activity (Clarke et al., 1998). We were puzzled, therefore, by the fact that an acute release of soluble TNF $\alpha$ from the myocardium begins immediately $(0-30 \mathrm{~min})$ upon post-ischemic reperfusion of the heart (Kupatt et al., 1999; Massoudy et al., 2000). Pertinently, this is a situation characterized by oxidative stress (Raschke et al., 1993), and recent evidence suggests that oxidation of the crucial cysteine located at position 184 may acutely generate sheddase activity without a preceeding enzymatic removal of the entire switch (Gilles et al., 2001; Zhang et al., 2001). However, there is uncertainty concerning oxidative activation of TACE in situ and which cells express TACE in the myocardium, i.e., presumably serve as source for the liberated TNF $\alpha$. Another confusing issue is that a number of other metalloproteinases, including MMPs-1, -7, -9 and 17 and ADAM10, have been reported to cleave proTNF $\alpha$, and these proteases also are characterized by the presence of an inhibitory cysteine switch (Haro et al., 2000; English et al., 2000; Lunn et al., 1997).

Candidate cells capable of acutely liberating TNF $\alpha$ (within minutes) via the action of TACE or related metalloproteinases under the inflammatory and oxidative conditions of post-ischemic reperfusion include coronary endothelial cells, resident mast cells (Frangogiannis et al., 1998) and peripheral blood leukocytes (PBL), the latter becoming adherent and emigrating into the heart tissue in large numbers immediately upon reperfusion (Raschke et al., 1993; Zahler et al., 1999). Typification of suitable cells and elucidation of the mechanisms underlying activation of the sheddase(s) are confounded by the fact that pure cell cultures such as human umbilical vein endothelial cells (HUVEC) and HMC-1, a human mast cell-derived tumor cell line (Butterfield et al., 1988) that expresses TACE at the cell surface (Becker et al., 2002), do not generally express substantial amounts of pro-TNF $\alpha$ under non-inflammatory conditions. Indeed, initial hopes of being able to measure the release of TNF $\alpha$ into the medium (ELISA assay) or the shedding of TNF $\alpha$ from the cell 
membrane directly (flow cytometry) were not realized (Becker et al., 2002).

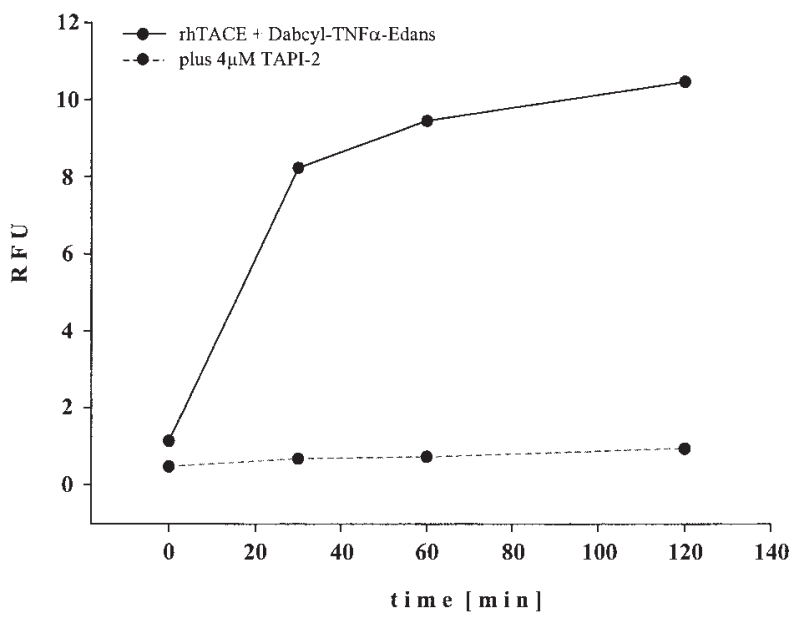

Fig. 1 Inhibition of Human Recombinant TACE by TAPI. Human recombinant TACE (Cat-Dis domains, from Arg 215 to Asn $671 ; 1 \mu \mathrm{g} / \mathrm{ml}$ ) was incubated at room temperature in $50 \mathrm{~mm}$ Tris (pH 7.4) with $10 \mu \mathrm{m}$ Dabcyl-TNF $\alpha$-Edans (Dabcyl-Leu-AlaGln-Ala-Val-Ser-Ser-Ser-Arg-Edans; Bachem, Heidelberg, Germany) in the absence or presence of $4 \mu \mathrm{M} \mathrm{TAPI}-2$ [N-(R)-(2-(hydroxyaminocarbonyl)methyl)-4-methylpentanoyl-L-t-butyl-GlyL-alanine-2-aminoethylamide, Immunex, Seattle, USA and Peptides International, Louisville, USA]. The plot shows one of 4 similar experiments. RFU = relative fluorescence units .
Prolonged inflammatory prestimulation of the cells to induce TNF $\alpha$ was no option, because we needed to mimic the actute oxidative stress imposed on cells in myocardial tissue during early reperfusion. Frequently, ersatz markers of shedding of TNF $\alpha$ are determined, for instance shedding of TNF $\alpha$-receptors or of L-selectin (Zhang et al., 2001), but their kinetics of cleavage by TACE could be different from those of TNF $\alpha$. Alternatively, employing peptide substrates with sequences identical to the scissile region of pro-TNF $\alpha$ in the absence and presence of known inhibitors of TACE (such as TAPI-2) to probe the activity of endogenous TACE could provide a possible solution (Black et al., 1997; Zhang et al., 2001). However, extension of this technique to whole cells and tissue homogenates has not been reported.

We first verified that the small peptide Ac-SPLAQA* VRSSSR- $\mathrm{NH}_{2}$ and the cryptic fluorescent probe DabcylLAQA ${ }^{*}$ RSSSR-Edans, each encompassing the scissile amino acid sequence of pro-TNF $\alpha$, are proteolytically degraded by recombinant human TACE. Both substrates suffered the expected rapid cleavage when incubated with 'Cat-Dis' rhTACE (approx. $1 \mu \mathrm{M})$. In the latter case, this is illustrated by increase of fluorescence (Figure 1). In the case of Ac-SPLAQAVRSSSR- $\mathrm{NH}_{2}$ cleavage was specific, disappearance of the test peptide leading strictly to a 1:1 formation of Ac-SPLAQA (data not shown). TAPI-2

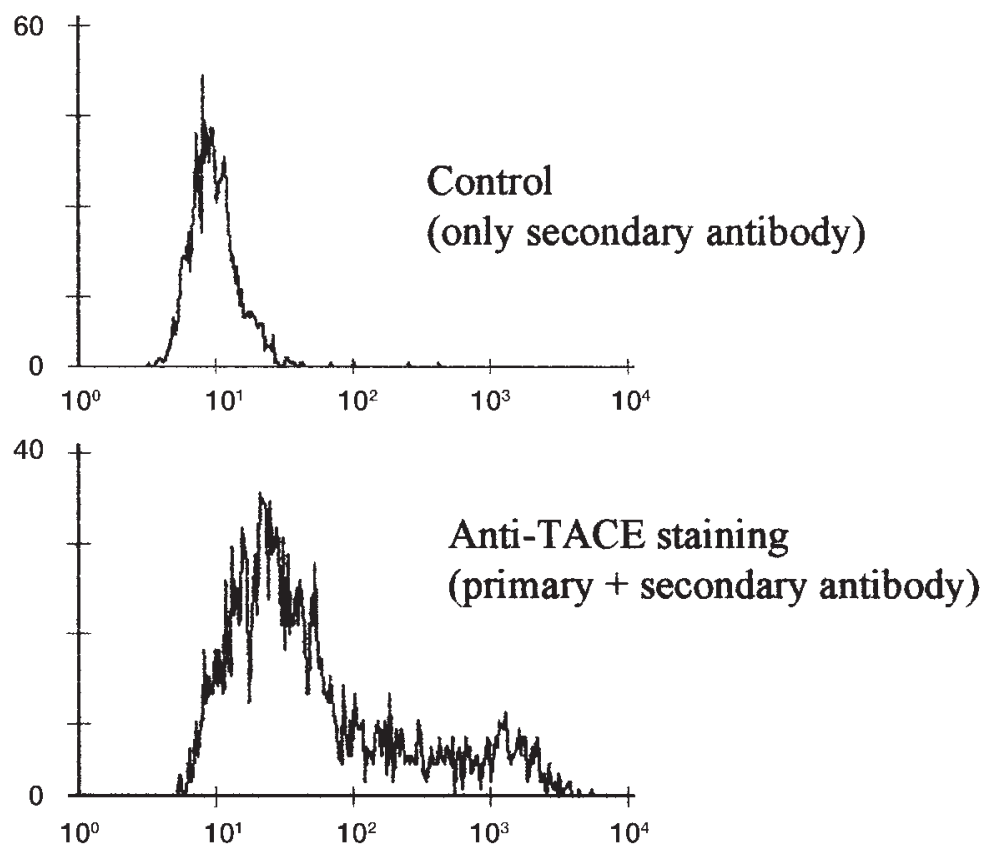

\section{Fluorescence intensity [relative units]}

Fig. 2 Flow Cytometric Demonstration of TACE on HUVEC.

Shown is a representative experiment of three cultures. HUVEC were brought into suspension with citrate buffer and fixed with $1 \%$ formaldehyde diluted in PBS (10 min, room temperature). After washing with Tyrode's buffer, $\mathrm{pH} 7.4$, and 3 rinsings with PBS, the cells were covered with $0.2 \%$ BSA in PBS for $10 \mathrm{~min}$ and labeled with primary antibody against human TACE $(1 \mu \mathrm{gg} / \mathrm{ml}$ huTACE-M222 from Immunex, in blocking buffer, $45 \mathrm{~min}$, room temperature) and secondary antibody carrying phycoerythrin (lower panel). Control with secondary antibody alone (anti-mouse lgG, 30 min incubation at room temperature, 3 washings in PBS, resuspension in Tyrode's buffer) is shown in the upper panel. 
inhibited cleavage of the substrates by rhTACE, giving about $50 \%$ inhibition at $0.01 \mu \mathrm{M}$ and and $95-100 \%$ at concentrations $>1 \mu \mathrm{M}$. The total inhibition of DabcylTNF $\alpha$-Edans cleavage caused by $4 \mu \mathrm{M}$ TAPI- 2 is exemplified in Figure 1.

Before commencing experiments with HUVEC and heart tissue, it was necessary to demonstrate the expression of TACE. Staining of non-permeabilized HUVEC with antibody against human TACE and subsequent analysis by flow cytometry revealed the presence of immunoreactive TACE on these cells (Figure 2). The intensity of expression was clearly non-homogeneous, some cells being without, and others with, high levels of TACE. Western blots of extracts of homogenized rat heart tissue using an antibody directed against the C-terminal (intracellular) end of the TACE molecule demonstrated two bands: the fainter one at a molecular mass of about $100 \mathrm{kDa}$, the far stronger band at approx. $80 \mathrm{kDa}$ (Figure 3, top). These molecular masses correspond roughly to those expected of the rat pro-enzyme with the cysteine switch attached and the furin-processed enzyme, respectively (Milla et al., 1999; Doedens and Black 2000; Swiss-Prot: www.expasy.ch/sprot/). Obviously, it is impossible to state from which cells or cell compartments this TACE is derived. The ratio of the two bands did not differ between hearts subjected to a protocol of ischemia and reperfusion and controls (Figure 3, bottom). These particular results are intriguing, since they do not support any extensive proteolytic activation of TACE in reperfused myocardial tissue, or even the need for any such conversion. However, facile cleavage of substrate peptides should be expected, both with HUVEC and homogenates.

Incubation of test peptides with whole cells (HUVEC, HMC-1, PBL) or heart tissue homogenates did not yield the same results as with rhTACE. Table 1 lists the extent of degradation of Ac-SPLAQAVRSSSR- $\mathrm{NH}_{2}$ co-incubated for 1 or $24 \mathrm{~h}$ with confluent HUVEC at $37^{\circ} \mathrm{C}$ in PBS. While no peptide remained intact for detection by HPLC after $24 \mathrm{~h}$ of contact with HUVEC, about $45-55 \%$ of the peptide was still detectable after $1 \mathrm{~h}$, also irrespective of oxidative (with $\mathrm{H}_{2} \mathrm{O}_{2}$ and $\mathrm{HOCl}$ ) or inflammatory pre-stimulation of the endothelial cells (see Table 1). This came as a surprise, because TACE is reportedly activated by $\mathrm{H}_{2} \mathrm{O}_{2}$ (Zhang et al., 2001). Moreover, TNF $\alpha$ shedding in the heart can be induced by intracoronary infusion of either $\mathrm{HOCl}$ or $\mathrm{H}_{2} \mathrm{O}_{2}$ (Gilles et al., 2001). As an additional discrepancy, TAPI-2 did not attenuate degradation, even at $50 \mu \mathrm{M}$. Importantly, under no condition was it possible to find the specific cleavage product Ac-SPLAQA (Table 1). This did not seem to be due to selective cellular uptake, because Ac-SPLAQA co-incubated with HUVEC over $1 \mathrm{~h}$ remained at a constant level in the supernatant (result not shown). Uptake of TNF $\alpha$-peptide into HUVEC cannot be excluded. Most likely, however, non-specific cleavage by other membrane proteases and peptidases may account for its disappearance. Preliminary experiments indicate that full inhibition of degradation can be achieved in the presence of protease inhibitor cocktail plus ortho-
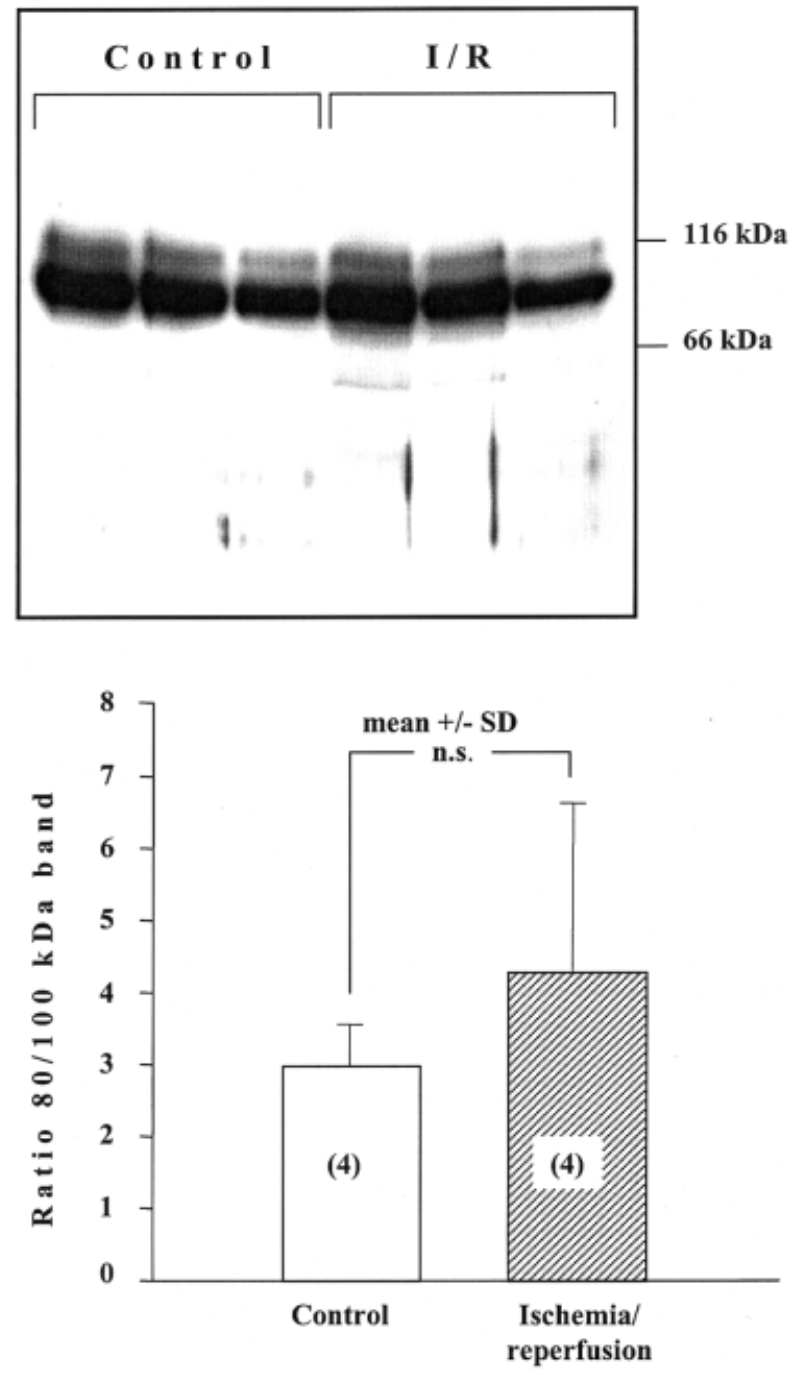

Fig. 3 Determination by Western Blotting of TACE in Homogenates of Isolated Perfused Rat Hearts.

Top panel: representative Western blot. Two bands were detected by TACE antibody/chemiluminescence. The upper (approx. $100 \mathrm{kDa}$ ) band presumably represents the unprocessed precursor (pro-TACE), while the lower (approx. $80 \mathrm{kDa}$ ) band corresponds to mature TACE (lacking the prodomain). Total protein loaded amounted to $50 \mu \mathrm{g}$ (lanes 1 and 4), $33 \mu \mathrm{g}$ (lanes 2 and 5) and $25 \mu \mathrm{g}$ (lanes 3 and 6 ). Bottom panel: ratio of unprocessed to mature TACE in control hearts and hearts subjected to $15 \mathrm{~min}$ global ischemia $\left(37^{\circ} \mathrm{C}\right)$ and $120 \mathrm{~min}$ of reperfusion. There was no significant difference between the two conditions (mean values $\pm \mathrm{SD}, \mathrm{n}=4, p=0.1$ by $t$-test). Heart tissue was homogenized in $50 \mathrm{~mm}$ Tris- $\mathrm{HCl}, 1 \mathrm{~mm}$ DTT, $100 \mu \mathrm{m}$ phenanthroline, 0.2\% Nonidet P-40, pH 7.4, mixed with Complete ${ }^{\circledR}$ protease inhibitor cocktail (Roche Diagnostics, Mannheim, Germany). The samples were boiled for $7 \mathrm{~min}$ with 1/4 volume of $4 \times$ loading buffer (250 mu Tris- $\mathrm{HCl}, \mathrm{pH}$ 6.8; 8\% SDS; $40 \%$ glycerol; $0.02 \%$ bromophenol blue; $400 \mathrm{~mm}$ mercaptoethanol), and loaded on a $10 \%$ SDS polyacrylamide gel. After blotting onto a nitrocellulose membrane with transfer buffer ( $39 \mathrm{~mm}$ glycine; $48 \mathrm{~mm}$ Tris base; $0.037 \%$ SDS; $10 \%$ methanol), proteins were blocked for $2 \mathrm{~h}$ (blocking buffer $50 \mathrm{~mm}$ Tris base, pH 7.5; $10 \%$ horse serum; $3 \%$ BSA; $200 \mathrm{~mm} \mathrm{NaCl} ; 0.05 \%$ Tween 20). Primary (rabbit antiTACE/ADAM17 polyclonal; Chemicon; 1:1000) and secondary antibody were diluted in blocking buffer. 
Table 1 Incubation of the TNF $\alpha$ Test Peptide Ac-SPLAQAVRSSR-NH $\mathrm{H}_{2}$ with HUVEC.

\begin{tabular}{llll}
\hline Incubation condition & $\begin{array}{l}\text { Amount of test } \\
\text { peptide remaining } \\
\text { (\% of initial) }\end{array}$ & $\begin{array}{l}+ \text { TAPI-2 } \\
(\% \text { of initial })\end{array}$ & $\begin{array}{l}\text { Formation of } \\
\text { Ac-SPLAQA }\end{array}$ \\
\hline $1 \mathrm{~h}$ & $59 \pm 6.5$ & $58 \pm 1$ & Not detectable \\
$1 \mathrm{~h}+\mathrm{H}_{2} \mathrm{O}_{2}(1 \mathrm{mM})$ & $54 \pm 11$ & $66 \pm 12$ & n.d. \\
$1 \mathrm{~h}+\mathrm{HOCl}(10 \mu \mathrm{MM})$ & $54 \pm 11$ & $59 \pm 2$ & n.d. \\
$1 \mathrm{~h}+\mathrm{IFN} \gamma$ & $46 \pm 9$ & - & n.d. \\
$1 \mathrm{~h}+\mathrm{TNF} \alpha$ & $51 \pm 8$ & - & n.d. \\
$1 \mathrm{~h}+\mathrm{LPS}$ & $45 \pm 6$ & - & n.d. \\
$1 \mathrm{~h}+\mathrm{PMA}$ & $52 \pm 9$ & - & n.d. \\
$24 \mathrm{~h}$ & 0 & 0 & n.d. \\
$24 \mathrm{~h}+\mathrm{H} \mathrm{O}_{2}$ & 0 & 0 & n.d. \\
$24 \mathrm{~h}+\mathrm{HOCl}$ & 0 & 0 & n.d. \\
\hline
\end{tabular}

TNF $\alpha$ test peptide $(2-20 \mu \mathrm{M})$ was incubated with HUVEC (confluent, first passage) at $37^{\circ} \mathrm{C}$ in the absence and presence of the TACE inhibitor TAPI-2 $(50 \mu \mathrm{M})$, added before test peptide (mean values $\pm \mathrm{SD}, \mathrm{n}=3-6, \mathrm{n} . \mathrm{d} .=$ not detectable). Interferon- $\gamma(\mathrm{IFN} \gamma, 250 \mathrm{ng} / \mathrm{ml})$, TNF $\alpha(2.5 \mathrm{ng} / \mathrm{ml})$ or lipopolysaccharide (LPS, $100 \mathrm{ng} / \mathrm{ml}$ ) were added to the cultures $24 \mathrm{~h}$ before peptide, $\mathrm{HOCl}(10 \mu \mathrm{M})$ and phorbolmyristate (PMA, $10 \mu \mathrm{M}) 10 \mathrm{~min}$, and $\mathrm{H}_{2} \mathrm{O}_{2}(1 \mathrm{mM}) 30 \mathrm{~min}$ prior to the test peptide. The supernatant was acidified with $0.4 \mathrm{M} \mathrm{HClO}_{4}$, centrifuged and analyzed by HPLC simultaneously for the 12-amino acid peptide substrate and the 6-amino acid fragment Ac-SPLAQA, one of the 2 TACE-specific cleavage products. The conditions used were: C18-Aqua ${ }^{\circledR}$ column (Phenomenex, Aschaffenburg, Germany), isocratic elution with $32 \% \mathrm{HClO}_{4}(\mathrm{pH} 2)$ in methanol $(41 \%)$ and water $(27 \%)$, peak detection at $200 \mathrm{~nm}$ (L-7400 detector, Hitachi-Merck, Darmstadt, Germany). Peak identification and calibrations were performed with substrate degraded by recombinant human TACE and with standard peptides (Biosource, Nivelles, Belgium). Retention times at a flow rate of $1 \mathrm{ml} / \mathrm{min}$ were $10.1 \mathrm{~min}$ for Ac-SPLAQAVRSSSR-NH $\mathrm{N}_{2}$ and $15.9 \mathrm{~min}$ for Ac-SPLAQA.

A

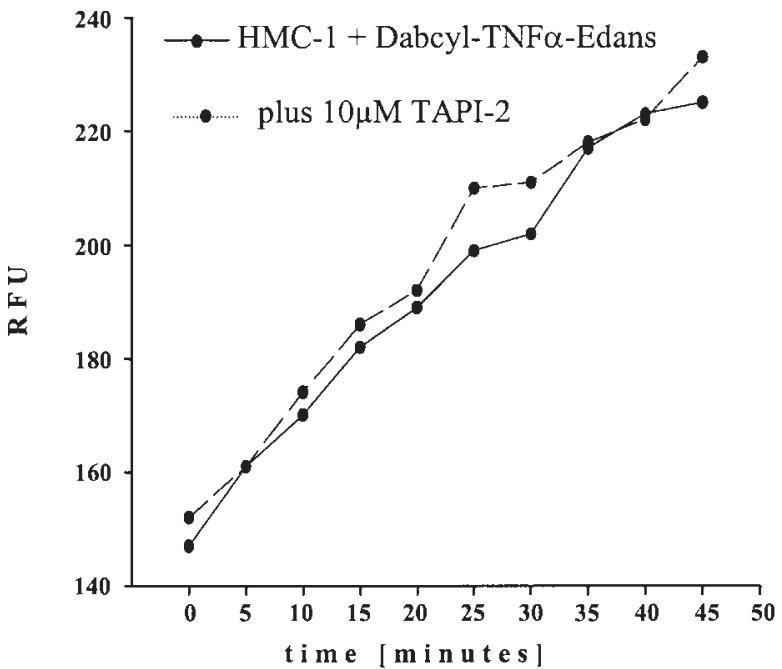

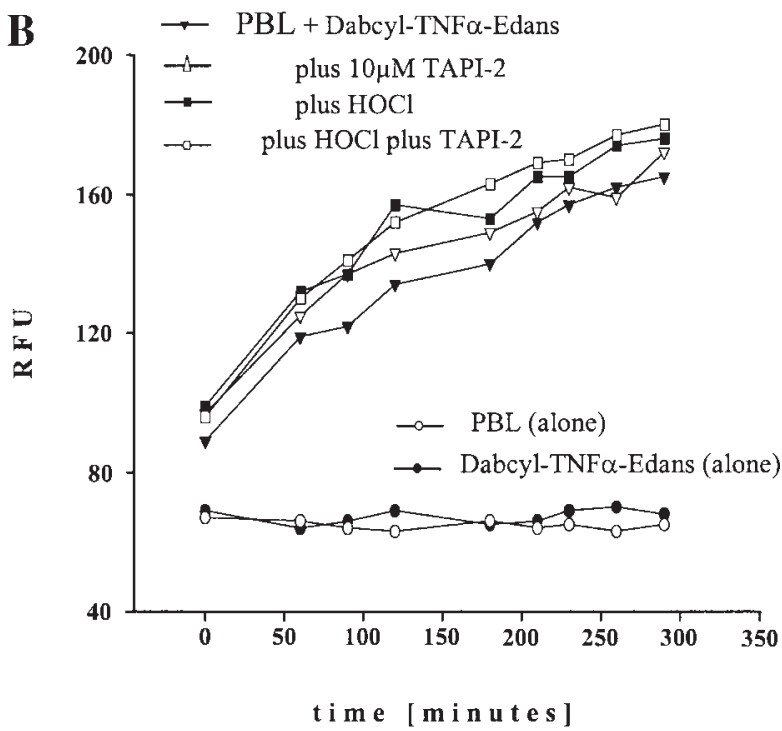

Fig. 4 Peptide Cleavage Assay with Whole Cells.

(A) HMC-1 cells $(10 \% / \mathrm{ml})$ incubated in Tyrode's buffer at $37^{\circ} \mathrm{C}$ with $10 \mu \mathrm{m}$ Dabcyl-TNF $\alpha$-Edans in the absence or presence of TAPI-2. (B) PBL $(106 / \mathrm{ml})$ in $250 \mathrm{~mm}$ Tris with $10 \mu \mathrm{m}$ Dabcyl-TNF $\alpha$-Edans. $\mathrm{HOCl}(10 \mu \mathrm{m})$ was added 10 min prior to peptide substrate. In each case, the Figure depicts one of 3 similar experiments. Development of fluorescence was monitored over a total period of 45 min (HMC-1) or $300 \mathrm{~min}$ (PBL) using a microplate reader (SPECTRAFluor plus, TECAN, Salzburg, Austria) with excitation at $355 \mathrm{~nm}$ and emission at $495 \mathrm{~nm}$. RFU = relative fluorescence units. The buffy coat obtained by centrifugation of fresh, citrated venous blood at $190 \mathrm{~g}$ for $15 \mathrm{~min}$ was mixed with $6 \%$ HES solution. The suspension was then centrifuged at $50 \mathrm{~g}$ for $10 \mathrm{~min}$, the supernatant transferred to a fresh tube and centrifuged again at $380 \mathrm{~g}$ for $10 \mathrm{~min}$. The pellet was resuspended in $5 \mathrm{ml}$ of calcium-free PBS and carefully layered over $5 \mathrm{ml}$ percoll (Pharmacia, diluted to a final density of $1.077 \mathrm{~g} / \mathrm{ml}$ ). After centrifugation for $25 \mathrm{~min}$ at $380 \mathrm{~g}$, the interphase (PBL) was collected, washed with, and resuspended in, calcium-free phosphate buffered saline $(\mathrm{pH} 7.4)$. 
phenanthroline, a universal inhibitor of metal-containing proteases (data not shown).

Fluorogenic Dabcyl-TNF $\alpha$-Edans peptide was cleaved by HMC-1 cells. However, the time-dependent increase in fluorescence was not influenced by TAPI-2, even when applied at the high concentration of $10 \mu \mathrm{M}$ (Figure 4A). Similarly, freshly isolated peripheral blood leukocytes (PBL) caused fluorescence when brought into contact with Dabcyl-TNF $\alpha$-Edans, but neither prestimulation of the PBL with oxidant $(\mathrm{HOCl})$ nor the presence of TAPI-2 $(10 \mu \mathrm{M})$ had any noticeable effect on the rate or extent of peptide cleavage (Figure 4B). No increase in fluorescence was observed when the reagent was kept in buffer without cells or when PBL were incubated alone. Previous studies with oxidants and HMC-1 cells had also failed to uncover TACE activation (Becker et al., 2002). It should be kept in mind that fluorescence of DabcylTNF $\alpha$-Edans is elicited by peptide cleavage at any site of the molecule. The reaction could, thus, very well be due to any number of peptidases or proteases expressed on the surface of $\mathrm{HMC}-1$ cells and PBL.

Since TACE should be present in the membrane of PBL, cells were lysed and various fractions prepared: cytoplasmic, soluble membrane and insoluble membrane. As demonstrated in Figure 5, fluorogenic substrate was cleaved by all 3 preparations at approx. equal rates. Again, TAPI-2 was without any significant influence. Fi-

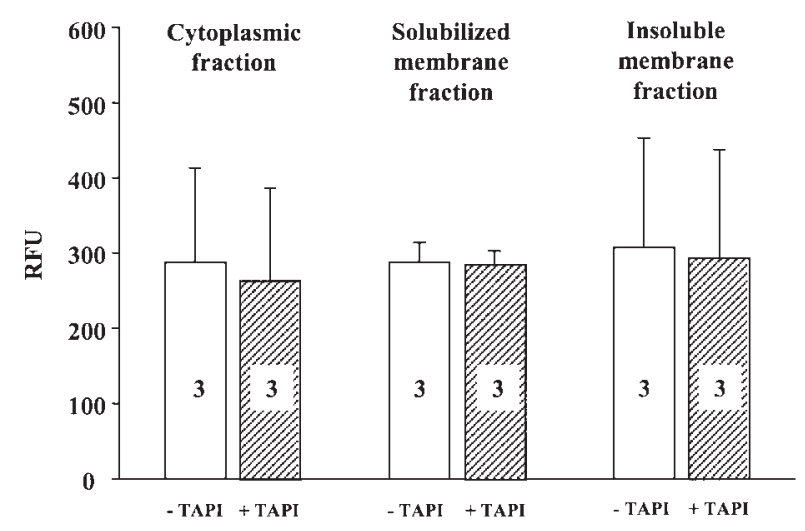

Fig. 5 TACE Activity in Cell Fractions of Lysed PBL.

Aliquots $(15 \mu \mathrm{l})$ of cytoplasmic, soluble or insoluble membrane fractions (suspension) were incubated with $10 \mu \mathrm{m}$ Dabcyl-TNF $\alpha$ Edans at $37^{\circ} \mathrm{C}$ in $200 \mu \mathrm{l}$ of $50 \mathrm{~mm}$ Tris $(\mathrm{pH} \mathrm{7.4)}$ in the absence or presence of $50 \mu \mathrm{M}$ TAPI-2. Fluorescence was measured after 60 min (mean values \pm SEM, RFU = relative fluorescence units). There were no significant effects of TAPI in any fraction (paired $t$ test). For lysis, $10^{7} \mathrm{PMN}$ in $50 \mu \mathrm{l}$ of PBS were alternatingly frozen $\left(5 \mathrm{~min},-20^{\circ} \mathrm{C}\right)$ and thawed $\left(5 \mathrm{~min}, 37^{\circ} \mathrm{C}\right) 5$ times. Lysed cells were then centrifuged $\left(20000 \mathrm{~g}, 15 \mathrm{~min}, 4^{\circ} \mathrm{C}\right)$. The supernatant corresponded to the cytoplasmic fraction, the pellet to membrane fractions. Pellets were resuspended in $30 \mu$ of solubilization buffer $(10 \mu \mathrm{g} / \mathrm{ml}$ leupeptin; $400 \mu \mathrm{m}$ benzamidine; $5 \mu \mathrm{m}$ pepstatin A; $2 \mu \mathrm{g} / \mathrm{ml}$ aprotinin; $1 \%$ Triton X-100 in PBS) and stirred lightly for 2 hours at $4^{\circ} \mathrm{C}$. Finally, these samples were centrifuged (20 $\left.000 \mathrm{~g}, 4^{\circ} \mathrm{C}, 30 \mathrm{~min}\right)$, solubilized membrane proteins being found in the supernatant, insoluble membrane components in the pellet. nally, tissue homogenates were prepared from isolated perfused rat hearts that had been subjected to transient global ischemia (15 min) and then reperfused for $65 \mathrm{~min}$, or that had been perfused without intermission (controls). As illustrated in Figure 6, fluorescence was emitted from Dabcyl-TNF $\alpha$-Edans in both types of homogenate, but there was no significant difference in the rate of substrate turnover. TAPI-2 (50 $\mu \mathrm{M})$ did cause a slight (approx. 10\%) reduction in fluorescence in each case (Figure 6), however, the effect was not statistically significant.

In conclusion, Cat-Dis TACE without the cysteine switch can readily cleave TNF $\alpha$ test peptides in vitro. Also whole cells can cleave the substrate peptides, but the contribution made by TACE seems marginal (non-specific cleavage, lack of inhibition by TAPI, avid cleavage by both membrane and non-membrane fractions of lysed $\mathrm{PBL}$ ). Alternative processes, such as degradation by other metalloproteinases or peptidases, and perhaps uptake into cells, dominate substrate turnover. Activation of proTACE is presumed to require removal of the cysteine switch by a furin-type enzyme (Black et al., 1997; Doedens and Black 2000; Milla et al., 1999; Skovronsky et al., 2001). Which form of TACE is present at cell membranes

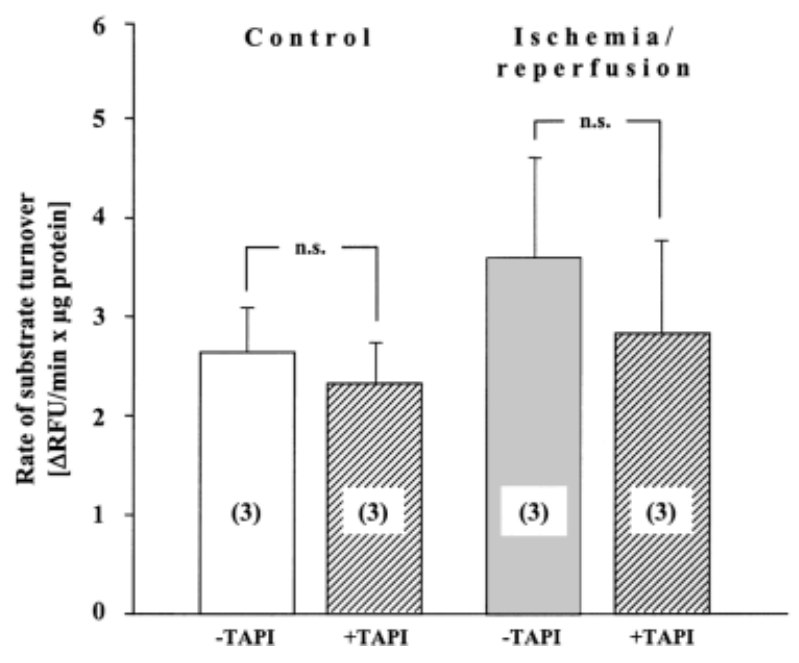

Fig. 6 TACE Activity in Rat Heart Homogenates.

Dabcyl-TNF $\alpha$-Edans (10 $\mu \mathrm{m})$ was incubated with rat heart homogenates in assay buffer for $45 \mathrm{~min}$ in the absence and presence of $50 \mu \mathrm{M}$ TAPI-2 and fluorescence was measured every $5 \mathrm{~min}$. Average rate of increase in fluorescence, normalized to amount of protein in the assay, is plotted on the ordinate (mean values $\pm S D$, n.s. = not significant). Ischemia/reperfusion (15 and $65 \mathrm{~min}$, respectively) did not significantly increase substrate turnover vs. homogenates from control hearts (80 min perfusion without ischemia). TAPI-2 treatment had only a slight inhibitory effect in both groups $(p=0.1$ for controls, $p=0.06$ for ischemia/reperfusion by paired $t$-test). Homogenates were prepared in buffer containing $50 \mathrm{~mm}$ Tris- $\mathrm{HCl}, 320 \mathrm{~mm}$ sucrose, $1 \mathrm{~mm}$ DTT, $10 \mu \mathrm{g} / \mathrm{ml}$ leupeptin, $2 \mu \mathrm{g} / \mathrm{ml}$ aprotinine, $10 \mathrm{~mm}$ $\mathrm{NaMoO}_{4}, 5 \mathrm{~mm} \mathrm{NaF}$ and $0.2 \%$ Nonidet P-40 (pH 7.4). Supernatants obtained by centrifugation $\left(20 \mathrm{~min}, 3900 \mathrm{~g}, 4^{\circ} \mathrm{C}\right)$ were diluted 1:10 in assay buffer (50 mm Tris- $\mathrm{HCl} ; 1 \mathrm{~mm}$ DTT; $10 \mathrm{~mm}$ $\mathrm{NaMoO}_{4} ; 5 \mathrm{~mm} \mathrm{NaF} ; 100 \mu \mathrm{M} \mathrm{ZnCl}$; $\mathrm{pH}$ 7.4); for details of heart perfusion, see Kupatt et al., 1999. 
is not quite certain (Schlöndorff et al., 2000). The failure to uncover TACE activity by imposing oxidative stress on the perfused heart prior to homogenization, or on cells in culture, may relate to the fact that TACE is already present largely in the pre-cleaved, mature form (Western blot data) or that alternative, redox-insensitive peptidases predominate. Thus, liberation of $17 \mathrm{kDa}$ TNF $\alpha$ from the post-ischemic heart may be more a question of acutely enhanced access of pro-TNF $\alpha$ to mature TACE. Certainly again open to question is whether TACE is really the sheddase primarily responsible for acute release of TNF $\alpha$ from the myocardium.

\section{Acknowledgements}

This work was supported by SFB469 of the German Research Council (DFG). We are indebted to Dr. Roy Black of Immunex Corporation, Seattle, WA, USA, for generously supplying TAPI-2, TNF $\alpha$-test peptide, active rhTACE and antibody against human TACE, and to Dr. Ulf Neumann, Novartis Pharma, Bern, Switzerland, for also providing rhTACE. Contacts to the above scientists were initiated by Dr. Marianne Jochum, Dept. of Clinical Chemistry and Clinical Biochemistry of the University of Munich, and we acknowledge this help.

\section{References}

Becker, B.F., Gilles, S., Gonscherowski, V., Gabrijelcic-Geiger, D., Sommerhoff, C., Welsch, U., and Zahler, S. (2002). Assessing experimental models in myocardial injury: lack of activation of the proteases TACE and calpain in brief ischaemia and reperfusion. Heart, Lung Circ., in press.

Black, R.A., Rauch, C.T., Kozlosky, C.J., Peschon, J.J., Slack, J.L., Wolfson, M.F., Castner, B.J., Stocking, K.L., Reddy, P., Srinivasan, S., Nelson, N. et al. (1997). A metalloproteinase disintegrin that releases tumor-necrosis factor- $\alpha$ from cells. Nature 385, 729-733.

Butterfield, J.H., Weiler, D., Dewald, G., and Gleich, G.J. (1988). Establishment of an immature mast cell line from a patient with mast cell leukemia. Leukemia Res. 12, 345-355.

Clarke, H.R., Wolfson, M.F., Rauch, C.T., Castner, B.J., Huang, C.P., Gerhart, M.J., Johnson, R.S., Cerretti, D.P., Paxton, R.J., Price, V.L., and Black, R.A. (1998). Expression and purification of correctly processed, active human TACE catalytic domain in Saccharomyces cervisiae. Protein Expr. Purif. 13, 104-110.

Doedens, J.R., and Black, R.A. (2000). Stimulation-induced down-regulation of tumor necrosis factor- $\alpha$ converting enzyme. J. Biol. Chem. 275, 14598-14607.

English, W.R., Puente, X.S., Freije, J.M.P., Knäuper, V., Amour, A., Merryweather, A., López-Otín, C., and Murphy, G. (2000). Membrane type 4 matrix metalloproteinase (MMP-17) has tumour necrosis factor- $\alpha$ convertase activity but does not activate pro-MMP-2. J. Biol. Chem. 275, 14046-14055.
Frangogiannis, N.G., Lindsey, M.L., Michael, L.H., Youker, K.A., Bressler, R.B., Mendoza, L.H., Spengler, R.N., Smith, C.W., and Entman, M.L. (1998). Resident cardiac mast cells degranulate and release preformed TNF- $\alpha$, initiating the cytokine cascade in experimental canine myocardial ischemia/reperfusion. Circulation 98, 699-710.

Gilles, S., Zahler, S., and Becker, B.F. (2001). Oxidative stress is essential for postischemic TNF $\alpha$ release of isolated rat hearts. Pflüger's Arch. - Eur. J. Physiol. 441 (Suppl.), R235.

Haro, H., Crawford, H.C., Fingleton, B., Shinomiya, K., Spengler, D.M., and Matrisan, L.M. (2000). Matrix metalloproteinase-7dependent release of tumor necrosis factor- $\alpha$ in a model of herniated disc resorption. J. Clin. Invest. 105, 143-150.

Kupatt, C., Habazettl, H., Goedecke, A., Wolf, D.A., Zahler, S., Boekstegers, P., Kelly, R.A., and Becker, B.F. (1999). Tumor necrosis factor- $\alpha$ contributes to ischemia and reperfusion-induced endothelial activation in isolated hearts. Circ. Res. 84, $392-400$.

Lunn, D.A., Fan, X., Dalie, B., Miller, K., Zavodny, P.J., Narula, S.K., and Lundell, D. (1997). Purification of ADAM 10 from bovine spleen as a TNF $\alpha$ convertase. FEBS Lett. 400, 333335.

Massoudy, P., Zahler, S., Freyholdt, T., Henze, R., Barankay, A., Becker, B.F., Braun, S.L., and Meisner, H. (2000). Sodium nitroprusside in patients with compromised left ventricular function undergoing coronary bypass: reduction of cardiac proinflammatory substances. J. Thorac. Cardiovasc. Surg. 119, $566-574$

Milla, M.E., Leesnitzer, M.A., Moss, M.L., Clay, W.C., Carter, H.L., Miller, A.B., Su, J.L., Lambert, M.H., Willard, D.H., Sheeley, D.M. et al. (1999). Specific sequence elements are required for the expression of functional tumor necrosis factor- $\alpha$-converting enzyme (TACE). J. Biol. Chem. 274, 3056330570.

Raschke, P., Becker, B.F., Leipert, B., Schwartz, L.M., Zahler, S., and Gerlach, E. (1993). Postischemic dysfunction of the heart induced by small numbers of neutrophils via formation of hypochlorous acid. Basic Res. Cardiol. 88, 321-339.

Schlöndorff, J., Becherer, D., and Blobel, C.P. (2000). Intracellular maturation and localization of the tumor necrosis factor $\alpha$ convertase (TACE). Biochem. J. 347, 131-138.

Skovronsky, D.M., Fath, S., Lee, V.M.-Y., and Milla, M.E. (2001). Neuronal localization of the TNF $\alpha$ converting enzyme (TACE) in brain tissue and its correlation to amyloid plaques. J. Neurobiol. 49, 40-46.

Zahler, S., Massoudy, P., Hartl, H., Hähnel, C., Meisner, H., Becker, B.F. (1999). Acute cardiac inflammatory responses to postischemic reperfusion during cardiopulmonary bypass. Cardiovasc. Res. 41, 722-730.

Zhang, Z., Oliver, P., Lancaster, J.R., Schwarzenberger, P.O., Joshi, M.S., Cork, J., and Kolls, J.K. (2001). Reactive oxygen species mediate tumor necrosis factor $\alpha$-converting, enzymedependent ectodomain shedding induced by phorbol myristate acetate. FASEB J. 15, 303-305.

Received January 18, 2002; accepted August 2, 2002 